\title{
Metaphoric Models of the Concept FIRE in Sakha and English Languages
}

\author{
Evdokiya N. Afanasieva and Raissa P. Ivanova* \\ Mirny Polytechnic institute (branch) \\ of Ammosov North-Eastern Federal University \\ 5/1 Tikhonova Str. , Mirny, Sakha Republic, 678170, Russia
}

Received 31. 03. 2015, received in revised form 04. 04. 2015, accepted 19. 05. 2015

The article deals with the study of concept FIRE in Sakha and English languages. Basing on the theory of conceptual metaphor the authors singled out metaphoric models of representation of concept FIRE in both cultures. The two languages have common universal and differential specific ways of conceptualizing the concept under study. They depend on the structure of both languages and also on cultural and historic background. The Sakha language displays pagan conception of fire as a living being expressed in the models FIRE IS A HUMAN BEING, FIRE IS AN OLD MAN. The metaphoric models found in the English language are connected with materialistic conception of fire in the models FIRE IS A MATERIAL OBJECT. The examples of personification in English convey humanlike characteristics of fire which is able to consume, dance, sweep, kill, die, etc. The Christian religion of the English reveals itself in the metaphoric model FIRE IS HELL which is a well-known allusion to the Bible. The identified models might be valuable for cross-cultural studies and cognitive linguistics.

Keywords: concept, fire, cognitive linguistics, conceptual metaphor, English language, Sakha language.

Research area: philology.

\section{Introduction}

The study of concepts of different languages has been a topical problem of linguistics for the last decade. The comparative study of the concepts contributes to the effective crosscultural communication and the development of the general methodology of conceptual studies.

The concept under discussion is one of the key concepts of any culture. People used fire since ancient times to survive. The analysis of the representation of the concept of fire in Sakha and English languages will show the development of it in both cultures and reveal common and differential features of the concept in two languages under study.

\section{The theory of cognitive metaphors} as the basis of analysis

Many linguists hold the view that our cognition is metaphoric (Lakoff, 2003; Fauconnier, 1985; Grady, 1999 and many others). Analyzing metaphoric models we dwell upon the postulates of the theory of conceptual metaphor worked out by G. Lakoff and M. Johnson. According to them

(C) Siberian Federal University. All rights reserved

* Corresponding author E-mail address: Raissa1@yandex.ru, Lukow@mail.ru 
the human conceptual system is metaphorically structured and defined. In their work metaphor stands for metaphorical concept (Lakoff, 2003: 7). As the authors write, the most fundamental values in a culture are coherent with the metaphorical structure of the most fundamental concepts (Lakoff, 2003: 23). The study of the concept FIRE as we believe will let us view one of the basic values of Sakha and English cultures.

Building metaphoric models of the representation of the concept FIRE we relied on the postulate of the theory of the cognitive metaphor which says that understanding our experiences in terms of objects and substances allows us to pick out parts of our experience and treat them as discrete entities or substances which the basis for ontological metaphors (Lakoff, 2003: 26).

In opinion of the founders of the theory the most obvious ontological metaphors are those where the physical object is further specified as being a person. This allows us to comprehend a wide variety of experiences with nonhuman entities in terms of human motivations, characteristics, and activities (Lakoff, 2003: 33).

The authors also observe metonymy which, as they state, serves the same purposes that metaphor does, and in somewhat the same way, but it allows us to focus more specifically on certain aspects of what is being referred to (Lakoff, 2003: 238). Like metaphors, metonymic concepts structure not just our language but our thoughts, attitudes, and actions. And, like metaphoric concepts, metonymic concepts are grounded in our experience. In fact, the grounding of metonymic concepts is in general more obvious than is the case with metaphoric concepts, since it usually involves direct physical or causal associations. When dealing with the concept FIRE we have also singled out metonymic models where human characteristics stand for the man in general, actualizing metonymic model PART FOR THE
WHOLE. As the authors note, the conceptual systems of cultures and religions are metaphorical in nature. Symbolic metonymies are critical links between everyday experience and the coherent metaphorical systems that characterize religions and cultures. Symbolic metonymies that are grounded in our physical experience provide an essential means of comprehending religious and cultural concepts (Lakoff, 2003: 41).

Let us make generalizing remarks on the main postulates of the theory of conceptual metaphor. Metaphors are fundamentally conceptual in nature, metaphorical language is secondary. Conceptual metaphors are grounded in everyday experience. Abstract thought is largely, though not entirely, metaphorical. Metaphorical thought is unavoidable and mostly unconscious. Abstract concepts have a literal core but are extended by metaphors. Abstract concepts are not complete without metaphors. The founders of the theory conclude: "We live our lives on the basis of inferences we derive via metaphor" (Lakoff, 2003: 273).

As the analysis of the linguistic data of both languages shows metaphorization was the basic means of interpreting the world for both English and Sakha languages. Let us view the metaphoric models in both languages.

\section{Conceptualization of FIRE in Sakha}

In modern Sakha language the word 'uot' has following meanings: fire, flame, campfire, light, flash, electric light and conflagration (IRS).

The analysis of Sakha linguistic factology shows that fire is mainly pictured as a human being. We could single out a set of anthropomorphic metaphoric models in Sakha language.

In Yakut mythology, the Spirit of Fire Khatan Temieriye is pictured as an old man. For Taiga people fire was one of the most necessary conditions of life and the object of particular attention, high adoration and reverence: "Fire 
spirit is the greatest of all spirits, who competes with much adored deity. A special cult was devoted to him" (Kulakovskii, 1979: 31). An ethnographer N. A. Alekseiev wrote: "according to the Yakut beliefs fire possesses supernatural power to exorcise the demon. Fire spirit was represented as a small grey-bearded old man (Alekseiev, 1975: 68-69).

Let observe the following example:

Kim ere uokka mas ebii byrakhta. Kutaa küöjüien küle-sala külübürüü tüste (Danilov) (Akademicheskaia kartoteka). (Somebody chunked the fire. The fire blazed up, bursted out laughing).

Fire, being personified in the example above is able to laugh and be satisfied after somebody had chunked it.

Fire is believed to be alive, fire spirit Khatan Temieriye was omniscient well-wisher of man. The latter was under his protection and treated him kindly. He could speak and consult with fire; by the crackling of the fire, he could tell the fortune.

The language has saved such idioms proving anthropomorphic perception of fire:

uot ette fire said (IRS),

uot tyla flame (literal: the tongue of fire) (STST),

uot ichchite spirit of fire (IRS),

The fire was also a medium to appeal to other spirits, such as Baianai, the spirit of Taiga: «Cross not my path, / Hinder not my pursuit, / Deprive me not of my delight!/ I am also feeding you by this warm fire, / I am also treating you by this blaming fire!» (Kulakovskii, 2003: 21-22).

uotu ahat - to feed the fire (this is a ritual of treating to fire spirit before or after some great event) (STST).

uot siebit burnt, be burned down (literal: the fire has eaten) (IRS);

uot salaabytyn kurduk empty (literal: as fire has licked) (Nelunov, 269).
Here we observed the metaphoric model FIRE IS AN OLD MAN which is a specification of the larger metaphor FIRE IS A HUMAN BEING.

Fire is compared with emotion. The analysis of the combinative potential of the word 'uot' shows a various ways of metaphorization. Combination of noun describing fire with the word 'taptal' love develops metaphorical meanings, denoting feeling of love. Love (taptal) is like fire:

taptal uota fire of love (STST),

taptal kyyma the spark of love (STST).

When greeting lovers the word 'taptal' is used with the adjectives designating temperature and gustatory senses:

uot taax taptal burning love (literal: fire love) (STST),

uokhtaakh taptal strong love (literal: hard love (STST).

Love, like a fire, burns and fades. One can see it in various combinations with the verbs meaning the temperature sense: umay- to burn, silamnaa- to lie in the sun, fire, uguttan- to warm, sögüree- to fade (IRS):

taptal uota umaida they fell in love, (literal: love fire has burnt) (STST);

taptal uota sögüreete they fell out of love (literal: love fire faded) (STST);

taptal uotugar sylamnaa to bask, to luxuriate (literal: to lie in love fire) (STST);

taptalga uguttan to be warmed with love (STST).

The intensity of speech is represented by means of the verbs denoting the burning of fire:

külübüree- to kindle, fig. to speak loudly and quickly (sayaran külübüreete he spoke loudly and quickly) (IRS);

küüdepchilen-flare up, fig. to burn into a rage (etihen küüdepchilenniler quarrel flared up) (IRS);

kytyalan-to blaze, fig. to rattle (IRS); 
küöjüi - to glow, fig. to enhance (yrya song, külsüü laughter, kör-nar merriment) (IRS).

The idiom uot aiakhg lib (quick) tongue (literal: fire mouth) (Nelunov, 267) denominate talkative wisecracker.

Gloomy spirit of a person is represented as a fading fire:

ös-to fade, be dying down, fig. to be upset (uota-küehe öspüt, umullubut his fire faded, sireye-xaraya öspüt he became upset) (IRS).

Thoughts and feelings of a man are associated with visual characteristics of the fire:

kylamnaa-to flash, fig. flash of thought, hope (erel kyyma kylamnaata flash of hope; sanaa kylam gynna an idea flashed across) (IRS);

sakh- to light fire, fig. to start a good thing, to ispire (saya sanaany sakh to inspire new idea) (IRS).

In the above examples we observe the actualization of the model FIRE IS EMOTION.

Hostility, difficult relationships between people are also expressed in terms describing fire:

kerdügennee-to burn under the earth, fig. smoulder (ös-saashostility);

küörtee-to blow fire with bellows, fig. to provoke (etihiini quarrel, mökküörü argument);

küöjüt - to set fire fig. to start, (etihiini quarrel, oxsuhuunu fight) (Akademicheskaia kartoteka).

Here we viewed the abstract model FIRE IS HOSTILITY.

Fire is a danger for man. The combination of the noun 'uot' within imperative sentences displays fire as a cataclysm. One shouldn't play games with fire:

uot suohuur fire gives out warmth

uottan seren- be aware of fire;

uottan serekhteex buol- be careful with fire;

uottan kuot- to run away from fire;

uottan byyhaa- to save from fire.

uokka byljat atfire took away; uotunan oonn'oomo don't play games with fire (Akademicheskaia kartoteka). Uottan serekhteekh buol, otuulammyt sirger uokkun üchügeidik umuruor. Kyym. Be careful with fire, blow it out when leaving the stand (Akademicheskaia kartoteka).

The words 'uu' water and 'uot' fire combine with each other in pair-word. Water and fire are represented as necessary but dangerous things for a man that should be treated carefully:

uuga-uokka tüher to rise alarm (lit / to fall into water and fire) (Nelunov, 281);

uuga-uokka serekhteekh buol- be careful with water and fire;

Uuga-uokka serenen, aiylyayytygar duohuia synn'anyy. Kyym. Be careful with water and fire, and have a good rest in the woods (Akademicheskaya kartoteka).

So the model FIRE IS DANGER is actualized.

The analysis of the linguistic material also lets us speak of metonymic model FIRE IS SENSATION.

In the example below the word 'uot' precedes the attribute meaning audial and temperature sensation:

uot umaiar tyaha the sound of burning fire;

uot itiite the warmth of fire;

uot suoha the strength of fire;

uot syralyana the heat of fire (Afanasieva, 102).

Here the noun 'uot' follows the attribute designating visual sensation:

kün uota sun light;

yi uota moon light;

chayylyan uota lightning;

tünnük uota window light;

chümechi uota candle light (laampa uota

lamp light, banaar uota lantern light);

ört uota spring grass fire; ört uotun yytallar they fire last year grass,

kuorat uota lights of a settlement; 
kharakh uota flash of eyes (Afanasieva, 102).

The word 'uot' follows the adjective of visual perception in the following examples:

kyhyl (küöx, arayas) uot red (green / blue, yellow / orange) fire;

syrdyk uot bright light;

xarana uot dark light;

boloorkhoj uot dim light;

charylkhai uot bright light;

umullubut uot faded light;

umullubat uot eternal light (Afanasieva, 103).

The interjection abytai denotes a pain sensation: uot abytai buola tüste he screemed from scorch, similar combinations testify the development of the meaning of intensity realized by the word uot: uot aljarkhai buolla (buola tüste) a big alarm happened, uot xaraxxa ette he stroke home (Afanasieva, 103).

The linguistic analysis of the Yakut language revealed the following metaphoric models: FIRE IS A HUMAN BEING (OLD MAN), FIRE IS EMOTION, FIRE IS HOSTILITY, FIRE IS DANGER, FIRE IS SENSATION.

\section{Conceptualization of FIRE in English}

The analysis of English lexicographical resources conveys that fire in the English language is represented as flames, shoot and emotion (CALDT), uncontrolled flames, light, and heat that destroy and damage things (LDCE), the state of combustion in which inflammable material burns, producing heat, flames, and often smoke (CED).

Let us dwell on the metaphoric models connected with the concept of fire in the English language.

As the analysis of the linguistic material displays, the majority of models are anthropomorphic, where fire has all the characteristics of a human being.

The central model accordingly is FIRE IS A HUMAN BEING.

The following examples decipher humanlike features of the fire, as it is able to dance, consume, escape, and kill:

The Fire Ghost simply bursts into flames, its spectral body surrounded with a huge halo of dancing fire (BNC).

He longed for thick felt against those dancing panes of fire (BNC).

In 1541 a fire consumed most of the town and much of the castle (BNC).

This was by far the most pleasant room in the school for it backed onto St. Martin's Church and in the far left hand corner was a door, normally open during the summer, leading to the fire escape (BNC).

More than 200 people, mostly women, were killed by a fire in a Thai toy factory, the worst industrial fire in history (BNC).

Black smoke gushed out of open doors and through windows and roofs only to be suddenly consumed by tongues of fire that licked heavenwards, raising up their flaming fangs like the arms of satanic dancers placating some obscene god (BNC).

In the above example the personification is obvious as fire is thought not only as able to consume but also to have a tongue as a human being. Moreover in the last two sentences the instrumental preposition by indicates the fire as an active doer of an action also actualizing personification.

In the following example fire as a human being is able to sweep metaphorically:

A young girl has been made homeless after fire swept through her bedsit home in Eldon Street, Darlington (BNC).

Another model containing personification is FIRE IS A LIVING BEING where one can 
observe the conceptualization of fire as an animal or a human being who is able to rage, roar and die as all living beings:

A massive forest fire is still raging in western Java (LDCE).

Then the fire died down and Isambard's more timorous followers came hurtling after him, and by sheer weight swept their opponents before them down the hillside (BNC).

$\mathrm{Mr}$ Trotter sat by the roaring fire LDCE).

The upper model can be considered both anthropomorphic and zoomorphic.

One can also highlight metonymic models where fire functions as qualities of a human being.

The most general model here is FIRE IS EMOTION:

Fire means strong emotion (CALDT):

The fire in her speech inspired everyone (CALDT).

a very strong emotion that makes you want to think about nothing else ( $L D C E$ ).

the fire of religious fanaticism ( $L D C E)$

fervent or passionate emotion or enthusiasm $(O A L D)$ :

Tony's fire and enthusiasm has always been a delight, but desire gets you nowhere by itself (OALD).

It was a great team effort with the lads playing with fire, passion, determination and a tremendous will to win (OALD).

It was played with passion and fire, by a massive orchestra (OALD).

In the examples above the noun fire combining with the abstract nouns enthusiasm, passion, determination, will as their synonym lets us speak of the meaning of passionate emotion and enthusiasm.

If combined with personal locatives (in her, in his eyes, in his belly) fire represents such emotions like passion and desire:
Day after day, she did what was expected of her and there was so little fire left in her that, when Mr Landor emptied a jug of red wine over a white damask tablecloth and kicked in her direction a cushion which split and sent feathers flying everywhere, she said not a word (BNC).

Ali returned to boxing with a new fire in his belly (LDCE).

He is like a prizefighter determined to show that there is still some fire in his belly (OALD).

The minister, who had red hair and fire in his eye, started on an upbeat note (BNC).

The emotional model can also be specified in the meaning 'be extremely angry' in the idiom 'breathe fire' (OALD):

As a strong police posse stood around watching, district fan club members gathered, forming an angry group and breathing fire at the critical references to their hero (OALD).

The new health minister entered the ring with the group breathing fire, promising a knockdown, drag-out struggle to the death, vowing there would be no retreat (OALD).

In the example below we see personification and a mythical interpretation of fire:

It then argues that this very desire for God is God immanent in man's being and shows how it may, in his particular case, come to inform all sides of his life which are reconciled as they are turned into fuel to feed the fire of love-itself lit in his desire for God (BNC).

Another metonymic model is FIRE IS PAIN SENSATION the actualization of which we can observe in the following examples of comparison:

The minute her hand made contact with the metal a very sharp pain that felt like fire ran up her entire arm (OALD).

Brad's eyes bugged out and he clutched his face as pain like fire ripped through his head (OALD). 
Some contexts demonstrate the model FIRE IS A PLEASANT SENSATION:

She cried aloud in joyous elation, her body still on fire, holding on to the magical moment as long as she could (BNC).

The context analysis shows that the person experienced a pleasant sensation as the preceding context (She cried aloud in joyous elation) bearing positive meaning, and also the following (magical moment) point out the meaning of fire as of a pleasant physical sensation.

The combination of the word 'fire' with the verb expressing feeling and emotions (feel) brings to the development of the new meaning of pleasant sensation in the following example:

She felt on fire, and thoughts tumbled pellmell in her head-Jenny, and his effrontery $(B N C)$.

The conceptualization of fire is not limited merely to anthropomorphic and zoomorphic models. The language material testifies the existence of the metaphoric model FIRE IS AN ABSTRACT NOTION which has the following variations:

\section{FIRE IS DANGER}

One can notice negative interpretation of the concept fire in the English language, where it is perceived as something dangerous, able to cause damage and destroy something:

Flames, light, and heat that destroy and damage things (LDCE):

The library was badly damaged in the fire (CED).

The warehouse was completely destroyed by fire (LDCE).

In the entry below we see the actualization of the model FIRE IS DIFFICULTY:

go through fire (and water) (for somebody), old-fashioned to do something very difficult and dangerous for someone ( $L D C E$ ). Let us illustrate the entry by the examples:
I would have gone through fire for Peter Docherty (BNC).

In the above context the person would stand all difficulties for the sake of her sweetheart (Peter Docherty).

In the example below the combination of the noun 'fire' with the verb 'to endure' develops the meaning of difficulty:

I would endure fire and flood and the agonies of the world (BNC).

\section{FIRE IS POWER}

In this metaphoric model one can observe fire as something very powerful which should be put out and fought with:

It took firefighters several hours to put out the fire ( $L D C E)$.

We have also taken the opportunity in the Bill to provide for water to be supplied free of charge for fire training purposes and for other emergency purposes as well as fire fighting (BNC).

The combination of the noun 'fire' with the verb 'to break out' which is a usual context for war, allows us to speak of the model FIRE IS WAR:

Residents were evacuated when fire broke out in a block of flats yesterday (LDCE).

In the idiom 'fire and brimstone' the word 'fire' has a religious meaning of hell, displaying the model FIRE IS HELL:

Viki looked at the two sympathetically, these two have been through hell fire and brimstone to be with each other (OALD).

It was on the subject he had been assigned by his apparently normal suburban Catholic school: Hell, and all its fire and brimstone (BNC).

They had hymns, a sermon with fire and brimstone, and all the usual traditional elements (OALD).

Besides the above mentioned anthropomorphcic, zoomorphic and abstract models one can single out artifact models of 
representation of the concept of fire in the English language.

The metaphoric model FIRE IS A MATERIAL OBJECT can be illustrated by the following examples:

One of the plane's engines had caught fire (LDCE).

Those who play with fire, however archly, must expect to get their fingers burnt once in a while $(B N C)$.

Fire being something material can be caught, played with.

In some metaphoric models fire can be regarded as a MOVING OBJECT as it is combines with the verb of movement 'go' and 'come':

They could get hot water, but only after the fire had been going for a while and the back boiler had heated up (BNC).

They hadn't a clue where the fire was coming from (BNC).

Having observed the lexicographical and corpus linguistic data in the English language we have singled out the following metaphoric models:

FIRE IS A HUMAN BEING, FIRE IS A LIVING BEING, FIRE IS EMOTION, FIRE IS SENSATION, FIRE IS AN ABSTRACT NOTION (DANGER, POWER, WAR, HELL), FIRE IS A MATERIAL OBJECT, FIRE IS A MOVING OBJECT.

\section{Conclusion}

The careful examination of the metaphoric models shows that both Sakha and English have common and differential features of representation of the concept FIRE.

We can highlight the following common ontological models, which also seem to be universal for the majority of languages and cultures. These are metaphoric models FIRE IS A HUMAN BEING, FIRE IS A LIVING BEING,
FIRE IS EMOTION, FIRE IS SENSATION, FIRE IS AN ABSTRACT NOTION, FIRE IS A MATERIAL OBJECT, FIRE IS A MOVING OBJECT.

Differential features lie in the way these models are revealed, as the two languages have different structures, English being analytical, Sakha - agglutinating. Also the concepts are affected by the style of life the linguistic societies lead: one can notice that Sakha language lacks the meaning of fire as an armory unlike English (OALD, LDCE, CED), which can be explained by historic ground: Sakha people being mainly cattle-breeding tribe didn't use armory with gunpowder, they used a bow and some other means for hunting. The Sakha consider themselves a part of nature, but not its masters or conquerors which can be seen from the metaphoric models analyzed above. In Sakha it is difficult to find examples of the model FIRE IS A MATERIAL OBJECT. It is almost always personified.

Religion can also influence the creation and development of concepts. As we can see paganism of the Sakha led to the personification of fire as an old man KhatanTemieriye - spirit of fire. People feed him in order to succeed in hunting or other important occasions including talking to other spirits of higher rank. Christian religion of the English influenced the emergence of the ontological metaphor FIRE IS HELL which is a well-known allusion to the Bible.

The model FIRE IS SENSATION also is very specific for each culture. In Sakha audial, temperature and visual sensations are the 'target domain' of the conceptual metaphors, but in English the model is realized to denote mainly pain sensations.

The work may be useful for cross-cultural communication issues, lectures on linguistics and culture studies. 


\section{References}

1. Afanasieva E. N. Semanticheskaia modifikacii aleksicheskikh edinits v sovremennom iakutskom iazyke (Semantic modifications of lexical units in modern Sakha). Jakutsk, Izd. Dom SVFU, 2013. $172 \mathrm{p}$.

2. Akademicheskaia kartoteka iakutskogo iazyka Instituta gumanitarnykh issledovanii i problem malochislennykh narodov Severa SO RAN (Academic corpus of Sakha language by Humanitarian Institute on Northern Studies of Russian Academy of Science).

3. Aleksejev, N. A. Tradicionnyie religioznyie verovaniia iakutov v XIX-načale XX v. (Traditional religious beliefs of the Sakha in XIX-XXc. ). Novosibirsk, Nauka, 1975. 198 p.

4. Fauconnier, G. Mental spaces and conceptual blending. 1985. $210 \mathrm{p}$.

5. Grady, J. Blending and Metaphor (1999) Metaphor in Cognitive Linguistics. John Benjamin Press, pp. 101-124.

6. Kulakovskii, A. I. Nauchnyie Trudy (Scientific Works). Jakutsk, 1979. 483 c.

7. Kulakovskij-Exekülex, A. Je. Blagoslovenije Bajanaja - Baianai algyha (A blessing of Bayanai). Jakutsk, Bichik. 2003. 21 p.

8. Lakoff, G. , Johnson M. Metaphors we live by. London, The university of Chicago press, 2003. $272 \mathrm{p}$.

9. BNC - British National Corpus (2015), Available at: http: //www. natcorp. ox. ac. uk/ (accessed 10-28 March 2015).

10. CALDT - Cambridge Advanced Learners Dictionary \& Thesaurus (2015), Available at: http: //dictionary. cambridge. org/ (accessed 20 March 2015).

11. CED - Collins English Dictionary (2015), Available at: http: //www. collinsdictionary. com/ (accessed 20 March 2015).

12. IRS -Iakutsko-russkii slovar (Sakha-Russian dictionary) (1972). M. , Sovietskaia ensiklopediia, $604 \mathrm{p}$.

13. LDCE - Longman Dictionary of Contemporary English (2015), Available at: http: //www. ldoceonline. com/ (accessed 20 March 2015).

14. Nelunov A. G. IIakutsko-russkii frazeologicheskii slovar' (Sakha-Russian phraseological dictionary). Novosibirsk, SO RAN, Filial «Geo», 2002. - T. 2. 420 p.

15. OALD - Oxford Advanced Learners Dictionary (2015), Available at: http: //www. oxforddictionaries. com/ (accessed 20 March 2015).

16. STST - Sahalyy tyl sitimin tyljyta: aat tyl (Sakha dictionary of collocations). Jakutsk, JaGU, 2009. $109 \mathrm{p}$. 


\title{
Метафорические модели
}

\section{репрезентации концепта ОГОНЬ}

\section{в якутской и английской языковых картинах мира}

\author{
Е.Н. Афанасьева, Р.П. Иванова \\ Политехнический институт (филиал) \\ Северо-восточный федеральный университет \\ им. М. К. Аммосова в г. Мирном \\ Россия, 678170, Республика Саха (Якутия), \\ Мирный, ул. Тихонова 5/1
}

В статье моделируются метафорические способы репрезентачии конщепта ОГОНЬ на материале якутского и английского языков. Методологической основой исследования послужила теория концептуальной метафоры, разработанная Дж. Лакоффом и М. Джонсоном. Сравнительно-сопоставительный анализ лексикографических источников английского и якутского языков, а также Британского начионального корпуса показал, что конщепт ОГОНЬ в обоих языках обладает общими универсальными, а также национально-специфическими способамивыражения. Дляякутскойкультуры конщепт ОГОНЬ представляет собойкультурномифологическую ценность и выражен в образе духа огня - Хатан Тэмиэрийэ, олищетворения огня в виде мудрого покровителя и защитника народа Саха. В английской языковой картине мира огонь оличетворяется в виде человека, который потребляет (fire consuтеs), разрушает (destroyed by the fire), убивает (killed by fire), таниует (dancing fire). Христианская вера англичан проявилась в метафорической модели FIRE IS HELL, которая является известной аллюзией к Библии.

В обеих культурах огонь связан с эмочиями, однако в якутском языке преобладают метафорические модели, относящиеся к положительным чувствам и эмоциям (любовь, радость), в английском - негативным (гнев, ярость, боль).

Полученные данные могут быть использованы в качестве дополнительного материала для исследований в области когнитивной лингвистики и культурологии.

Ключевые слова: конщепт, огонь, когнитивная лингвистика, теория метафоры, якутский язык, английский язык.

Научная специиальность: 10. 00. 00- филологические науки 